\title{
The Unbearable Failure of Decentralisation in Turkey
}

\section{Yeşeren Eliçin}

\author{
https://doi.org/10.31297/hkju.20.3.4 \\ UDK $\quad 35.071 .6(560)$ \\ $342.25(560)$ \\ Original scientific paper / izvorni znanstveni rad \\ Received / primljeno: $\quad 3.4 .2020$. \\ Accepted/prihvaćeno: 24.7. 2020.
}

Due to the country's then drive towards European Union membership, a comprehensive administrative reform agenda had emerged in Turkey during early 2000s. But a brusque reversal of decentralisation reforms followed the 2010 constitutional referendum. The reform agenda adopted in the 2000s had been overturned to lead to an increasingly authoritarian and centralised power. This recentralisation movement had a direct impact on local governance, triggering a decline of local autonomy accompanied by the dismissal of elected mayors and city council members in some Kurdish-populated cities. The fast decay of democratic accountability was accompanied by clientelism and corruption. This paper tries to demonstrate how recentralisation in Turkey led to the erosion of local democracy through two analytical parameters used to assess

* Professor Yeşeren Eliçin, Political Science Department, Galatasaray University, Istanbul, Turkey (redovita profesorica Odjela za političku znanost, Sveučilište Galatasaray, Istanbul, Turska, e-mail: yelicin@gsu.edu.tr)

ORCID ID: https://orcid.org/0000-0002-4355-0972 
the quality of democracy: the first parameter concerns the level of political autonomy, while the second pertains to whether local administrations' decisions are safeguarded from arbitrary interference by the central government.

Keywords: decentralisation, local autonomy, recentralisation, local reform, local democracy

\section{Introduction ${ }^{1}$}

The growing theoretical literature on decentralisation examines different forms of decentralisation, basically political, administrative and fiscal (Litvack, Ahmad \& Bird, 1998; Falleti, 2005). However, little attention has been paid to the interrelationship between two subtypes of decentralisation, i.e. deconcentration and devolution (Santagati, Bonini Baraldi \& Zan, 2020; Cheema \& Rondinelli, 2007; Wollmann, 2007). Deconcentration, the weakest form of decentralisation, refers to "the transfer of administrative tasks from an upper to a lower layer of unit of state administration, typically through the establishment of regional or local field offices" (Wollman, 2007, p. 3). However, many authors claim that deconcentration and devolution reinforce one another and thus they are not considered as incompatible (Santagati, Bonini Baraldi \& Zan, 2020; Diederichs \& Luben, 1995; Cohen \& Peterson, 1999; Cheema \& Rondinelli, 2007; Cole, 2012).

Decentralisation is defined by Rondinelli (1981, p. 137) as a process of state reform that transfers or delegates the legal and political authority to plan, determine, and manage public functions from the central government and its agencies to subnational units or levels of government. Decentralisation has been promoted by international governmental organisations and policy think tanks with the intention of improving aspects of governance such as democracy, public participation, efficiency, transparency, and anti-corruption as well as issues of economic development. "Decentralization now encompasses not only the transfer of power, authority, and responsibility within government but also the sharing of authority and resources for shaping public policy within society. In this expanding con-

1 This research has been financially supported by the Galatasaray University Research Fund, under Grant 19.104.001. 
cept of governance decentralization practices can be categorized into at least four forms: administrative, political, fiscal, and economic." (Cheema \& Rondinelli, 2007, p. 6)

In the liberal tradition, decentralisation is the transfer of power from a central government to popularly elected local governments (Lipset, 1995, p. 335). "More practically, decentralisation is commonly revealed by the downloading of public functions to lower levels of government and, ideologically, is associated with various turns in governance in the late twentieth century, such as the neoliberalization of the state and New Public Management" (Loewen, 2018, p. 105). Several Nordic countries have long histories of decentralisation, and it has been widely recommended over the last four decades to strengthen democracy and economic adjustment in the countries with formerly authoritarian regimes. The transfer of substantial fiscal, political, and administrative duties to subnational levels of government is evident on a global scale. There are three different forms or increasing degrees of decentralisation, namely deconcentration (opening a branch office in another region), delegation (tasking a subnational government with carrying out certain functions), and devolution (allowing subnational governments to take over functions autonomously) as well as partnerships and privatisation (Rondinelli, 1981, p. 137; Loewen, 2018, p. 105). "A basic level of progress along each one of these dimensions - or what can be called minimum decentralization - provides local government with sufficient power for local democracy to emerge and then eventually consolidate. Assuming, again, that the national system is democratic, a local system becomes a democracy when elected local officials are expected to respond and be held accountable primarily to their constituents, carry out functions sufficient to engage the local public's interest, and exercise their legally established authority without being subjected to overriding financial or other constraints from unelected or non-local elected officials." (Bland, 2011, p. 72)

In other words, the right of citizens to participate in decision-making procedures on a local level promotes democracy.

A political trend of recentralisation and strengthening state control over local authorities is evident in and out of Europe (Kerléo, 2015, p. 795). Horga (2017, p. 67) argues that there is ample evidence that since 2007, recentralisation tendencies have prevailed in Central and Eastern European countries. Precipitated by political or economic crises, European states are currently rationalising decentralised structures in order to achieve economies of scale, according to Kerléo (2015, pp. 796-797). These re- 
forms indicate a clear recentralisation of states or, in the least reactionary cases, obstacles to decentralisation, exemplified by the deferral of longawaited reforms in Finland, Sweden, Portugal, Denmark, and Ireland. "Perceived failures of decentralization point to a trend of re-centralization of regional policy in CEE countries, on the part of both national and EU levels, potentially exacerbating the trend of increasing regional polarization within countries. The cases of Estonia and Hungary illustrate these tendencies, drawing attention to national responses and the need for a continued dialogue on institutional development and EU Regional Policy reform in order to better target regional inequalities." (Loewen, 2018, p. 103)

Kerléo (2015) proclaims that current local reforms inside and outside Europe have followed a similar political pattern of recentralising local power and reinforcing state control over local authorities. He also underscores that - midway between concentration and decentralisation - recentralisation not only implies a transfer of responsibility from local authorities to the state but also one that concentrates power in the more substantial of local authorities. Moreover, decentralisation is generally evaluated as an indicator of a state's structural evolution, particularly with respect to the principles of free administration and subsidiarity. According to Kerléo, recentralisation is justified by deliberate simplification of the local and by the rationalisation of structure in order to avoid the overlapping of responsibilities and governing authorities (p. 795). It concentrates local level power, effectively reorganising decentralisation without challenging it. Recentralisation promotes a mainly economic approach by depriving decentralisation of - or overlooking - its underlying democratic principles. Recentralisation, which echoes contemporary attempts to better distribute competences among the levels of local authority, corresponds to state rescaling - that is to say, an institutional reorganisation of decentralisation by the state itself on essentially economic bases (pp. 811-812, 819). In Turkey, central authorities claimed that their reforms marked the beginning of an era of recentralisation in which urban service delivery schemes would be rescaled to achieve economies of scale (Elicin, 2018; Yılmaz \& Güner, 2017, p. 230). However, this economic reasoning has not been confirmed, and on the contrary, municipalities have ended up being more reliant on state funding. In opposition to the subsidiarity principle, the benefits of proximity were eradicated by the reforms, which generated a deficit of local accountability. A more centralised local administration system, in which importance was specifically attached to the metropolitan level, was created (Yllmaz \& Güner, 2017, p. 230). In fact, 
recentralisation at the local level in Turkey strengthened the control of the central state over local administrations and accompanied the move of the national system away from democracy. So, unlike European cases, there is a significant interdependence between decentralisation and democracy, and recent recentralisation trends in Turkey can be interpreted as a direct threat to local democracy. Turkey's recentralisation policy favours the executive as the sole arbiter of social and economic policy at various levels of government and systematically blocks democratic contestation of its policies as it increasingly adopts an authoritarian stance (Tansel, 2019, p. 321). Röth and colleagues (2016) argue that "the main factor preventing movement towards a more decentralized Turkish state is the ideological distance between neo-liberal and culturally conservative national governments in Ankara and the Marxist and culturally pluralist mobilization of Kurdish political actors" (p. 586). The failure of decentralisation is closely linked to political conduct surrounding the Kurdish question; the regionalism and political autonomy that decentralisation would entail are both inconceivable for the Turkish state (Yildizcan, 2018, p. 139). Yildizcan stresses that the dynamic of recentralisation is a "natural tendency" in Turkey when one takes into consideration the fact that there are no regional political entities per se beyond provincial administrations which are firmly controlled by the central authorities. Municipalities have, therefore, always deferred to the strict authority of the central government.

In the early 2000s, a comprehensive administrative reform agenda emerged in Turkey due to both domestic and international factors. At the time, Turkey's candidacy for membership in the European Union was a key element at the national level. Indeed, Turkey projected the impression that it was attaching increased importance to reforming the government, public administration, and local administrations in the context of strengthening decentralisation and democratisation. Although the Adalet ve Kalkınma Partisi (AKP, or Justice and Development Party) government initially defended decentralisation and the downsizing of the state, the power and interference of the central government increased, especially in the areas of housing and social policy. A brusque reversal of the decentralising reforms followed the 2010 constitutional referendum. The democratic reform agenda adopted in the 2000s was overturned, leading to increasingly authoritarian, centralised power. Recentralising policies were implemented through legislation and later through more controversial legal means, like decree laws, which increased the power of the centre over local administrations. Finally, in April 2017, a narrowly approved 
referendum opened up an era of presidentialism in which power is concentrated in the hands of the executive without checks and balances. This drive toward recentralisation has had a direct impact on local governance, effectively making local administrations subservient to the whims of the president (Kuyucu, 2018, pp. 1171-1172).

This article demonstrates that - because its roots concerned the concentration of power at the central level rather than a preoccupation with efficiency - recentralisation in Turkey led to the erosion of local democracy. To demonstrate the devastating effects of recentralisation, I refer to Bland's (2011) framework of local democracy; however, I base my evaluation on two of the conditions underscored by Bland that I consider most critical for analysing the state of local administrations in Turkey.

The first question concerns the level of political autonomy. Local democracy must involve a minimum level of political autonomy to incentivise local officials to act on behalf of the citizenry (Bland, 2011, p. 73). The functions regularly fulfilled by local governments must have sufficient political significance for the citizens to realise that the decisions that affect their lives and communities are made by local administrations. So, do local administrations in Turkey have effective power to govern?

The second question concerns whether the local administrations' decisions are safeguarded from arbitrary interference by the central government and whether the arbitrary removal of locally elected officials is effectively precluded. The term "arbitrary" designates "procedures that are used or potentially used with some regularity, usually for a primarily political objective that does not in practice serve a clear local public purpose or the purpose for which they were intended" (Bland, 2011, p. 72). Precluding the arbitrary removal of locally elected officials is considered a critical component of local democracy. Indeed, Bland argues that the "arbitrary removal of elected local officials violates the expressed will of the locality" (p. 73). Although there are serious concerns about free and fair elections, freedom of expression, and free access to alternative media in Turkey, elections still constitute one of the rare institutions that reinforces democracy. This study combines both the existing literature and original research based on an analysis of pre-existing data, namely the texts of legislative reforms to the system of local governance as well as grey literature produced by institutions such as the Turkish Court of Accounts (Saylştisay Başkanlığl), TOKİ (Toplu Konut Idaresi Başkanlığl, the government-backed Housing Development Agency of Turkey), and individual municipalities. 


\section{The Effective Power of Local Administrations to Govern: Administrative and Financial Autonomy}

Administrative and financial decentralisation is imperative for local authorities to have a significant level of political authority (Dahl, 1971, p. 82; Bland, 2011, p. 74). The administrative autonomy of local administrations in Turkey has been limited by a series of legal and institutional reforms. On one hand, certain competencies of local administrations were gradually shifted to the central government, and interference by the central state in the affairs of metropolitan municipalities burgeoned. On the other, through the rescaling of several special provincial administrations (SPAs) in 2012, town municipalities and villages were abolished, 14 new metropolitan municipalities were created, and the revenues of local administrations were readjusted.

\subsection{Central State Domination of the Local Agenda}

In the last two decades in Turkey, a strong centralisation tendency stands out with respect to urban governance, and urban policy has also become instrumentalised in national politics as a result of the financialisation of urban redevelopment. For this reason, central state interventions in urban space have multiplied, especially in Istanbul. The then Prime Minister Recep Tayyip Erdoğan presented and imposed his personal "big projects" for Istanbul during his national election campaign in 2011. These were comprised of the renovation of Taksim Square, which gave rise to the Gezi protests; a third bridge over the Bosphorus; Canal Istanbul (an artificial waterway paralleling the Bosphorus); a third airport; and Galataport (a retail-oriented landing for cruise ships), among others. Erdoğan proclaimed "mad projects" for other cities, as well, like the Northern Aegean Port of Çandarl in Izmir, which was to transform the area into one of Turkey's most important logistics hubs. In Istanbul, where such projects were severely contested by the civil society, the AKP-affiliated mayor remained on the sidelines, leaving the stage to central authorities. The concern with these projects is that they were launched without any reference to the urban policies and physical plans developed by the city itself. Moreover, the Canal Istanbul project even contravenes a national policy advocating the reversal of the densification of urban populations, particularly in Istanbul (see the country's $10^{\text {th }}$ and $11^{\text {th }}$ five-year plans); the project provides for the creation of a satellite city of at least 500 thousand inhabitants. Yet, on 
25 March 2020, the government held the first tender for the project when the country was battling the COVID-19 pandemic. $^{2}$

Interventionism at the local level of city management opened up important opportunities for central actors. Some existing institutions were remodelled and empowered to facilitate intervention by the state. They were transformed into extremely powerful central actors that controlled the creation and allocation of urban rent previously controlled by municipalities. Consequently, municipalities gradually lost power to central authorities, namely the Ministry of Environment and Urbanisation and TOKI.

The prerogatives of TOKI, which was originally established in 1984 to finance collective housing cooperatives organised by the middle classes, have grown considerably since 2001 through a number of legal directives. In 2004, the real estate assets of the General Directorate of Building Land Office were transferred to TOKI (Law No. 5273 of 15 December 2004), which was authorised to be involved in land banking and the expropriation of land for housing, education, industry, health, tourism, and public institutions. It was thus transformed into the country's largest public landowner and real estate developer and enjoyed the power to regulate all development of public land. Indeed, housing construction is now only one facet of TOKI's activities; it also undertakes the construction of mosques, stadiums, sports facilities, schools, viaducts, dispensaries, police stations, prisons, private hospitals, and shopping centres.

However, the source of TOKI's supremacy is that it is endowed with exceptional, even hegemonic power to undertake urban planning. In 2004, it acquired urban planning rights over large stocks of public land that came into its possession at no cost, as well as over all public land reserved for mass housing and squatter prevention. In other words, it became an aggrandised planning powerhouse (Law No. 5273 of 15 December 2004). Another one of TOKI's critical powers concerns urban renewal. Legislation on urban transformation attributed important planning, regulation, and investment powers to TOKI, turning it into the most important player in the urban land market.

The Law on Urban Transformation (Law No. 6306 of 16 May 2012) empowered the Ministry of Environment and Urbanisation as well as TOKI, restraining municipal authorities via the centralisation of urban planning

2 Yackley, A. J., Turkey mulls full lockdown to check coronavirus, https://www. al-monitor.com/pulse/originals/2020/03/turkey-considers-total-lockdown-coronavirus. html\#ixzz6ITHn7bqj 
(Elicin, 2014, p. 150). TOKI', which was previously under the charge of the prime minister, was attached to the Ministry of Environment and Urbanisation in 2018. It maintains a top-down, hierarchical relationship with local authorities, which are neither consulted nor invited to participate in TOKI's interventions. Another remarkable indicator of the centralisation of urban planning is the ratio of executive decisions made by the cabinet in the field of urban redevelopment, which increased to $45 \%$ in 2014 up from $5 \%$ in 2009. The most important of these decisions concern expropriations for large infrastructure works and urban regeneration projects (Kuyucu, 2018, p. 1158). Kuyucu also underscores the number of interventions by TOKI that nullified the decisions of local administrations (p. 1159). Indeed, in Kartal, one of the second-tier municipalities of Istanbul, TOKI turned an area declared by the municipality to be an urban transformation zone into a "special project area" and constructed residential towers there, notwithstanding strong opposition from the municipality.

The central state's other initiative reflecting its aspiration to recentralise and strengthen control over local administrations concerns data and information operating systems run by local administrations. According to an amendment to the Law on Municipalities (Law No. 5393 Amendment 3 of 15 February 2018), all municipalities are to collect their data on an e-municipality system created and controlled by the Ministry of Environment and Urbanisation in cooperation with the Ministry of the Interior. Thus, they cannot maintain independent data and information operating systems.

\subsection{Rescaling at the Local Level}

Another centralisation policy of the government involved major territorial and administrative rescaling at the metropolitan level: 14 new metropoli$\tan$ municipalities were created in 2012, increasing the total number to 30. The new regulation abolished SPAs, which were local provincial administrations, and extended the purviews of the new municipalities to the borders of the province. The population criterion was also adjusted. Previous legislation had designated that an urban population of 750 thousand was necessary to create a metropolitan municipality, but the new benchmark was 750 thousand inhabitants living anywhere within provincial limits - including the residents of sparsely populated rural territories. Consequently, with the doubling of metropolitan provinces across the country, metropolitan municipalities came to account for $50 \%$ of the geographical 
area and $76 \%$ of the national population, irrespective of geographic and demographic contingencies (Arıkboğa, 2013, p. 71). An initial purge was realised in May 2008 when municipalities with less than 5,000 inhabitants were eliminated. This rescaling resulted in the eradication of a significant number of town and district municipalities along with SPAs in metropolitan provinces, which entailed a drop in the number of locally elected representatives. "A more consolidated model of metropolitan government was established without addressing the decline in democratic representativeness of the new model (as the number of seats that were lost by closing down small-scale municipalities were not compensated for in the remaining elected offices)" (Beltan, 2018, pp. 96-97). The new model also involved a transfer of responsibility to the largest local authority - that is, to the metropolitan municipality - hence a recentralisation was taking place at the metropolitan level. The 2012 reform, which adopted a topdown, heavy-handed approach that abolished almost half of the country's municipalities without any referendum or consultation with citizens, was deemed a violation of the constitution and the European Charter of Local Self-Government and therefore a threat to local democracy by many authors (Gözler, 2013; Elicin, 2018; Yılmaz \& Güner, 2017).

According to Bayraktar (2018), the failure of reforms in 2004 that had bolstered the sanction of the governor-ruled SPAs triggered their subsequent abolition (p. 121). Yet these governors, who were particularly crucial in the cities ruled by the opposition, were immediately compensated with a pivotal role in Investment Monitoring and Coordination Directorates (IMCDs) created by the 2012 reform in metropolitan provinces where SPAs had been abolished. These directorates were established to develop the participation and potential of regional actors as a means for the central state to counterbalance its new scalar strategies. The IMCDs resulted in the allocation of extra powers to governors and district governors (Yildizcan \& Bayraktar, 2017, p. 4), who were placed at the head of these new structures of governance. The governors and district governors thus gained significant influence over local administrations and the design of local policy as they had the arbitrary power to choose who would participate in policymaking.

During the state of emergency declared after the failed 2016 coup, these directorates were given additional powers by Decree Law No. 674, which was liable to jeopardise local autonomy. First, they were given more prerogatives and financial resources as well as legal personhood, which can be interpreted as administrative centralisation. Second, the decree further stipulated that in the case of a disruption to the services and investment 
carried out by public institutions, governors could undertake the delivery of these services through the IMCDs. (In normal circumstances, in the case of such an insufficiency or disruption of service provision, a judge would warn the municipality and the delivery of the services in question would be demanded from the Ministry of the Interior. Only in cases where this request was not fulfilled was the governor authorised to intervene.) A second imposition that jeopardised local autonomy was that the decree law specified that in the fight against terrorism and violence, the governor could designate an institution (most probably the IMCD) that could be put in charge without needing the approval of the judiciary. According to Keleş and Özgül (2017), this violates the constitution as it establishes a hierarchical relationship between central authorities and local administrations that far exceeds tutelage and that evinces recentralisation (p. 303). So as a result of the legal amendments adopted during a state of emergency, there was a strong shift in favour of recentralisation with respect to the relationship between central authorities and local administrations.

\subsection{Financial Autonomy}

Financial autonomy is a sine qua non condition for a local administration system to fulfil its responsibilities (Bland, 2011, p. 75). Sufficient financial resources of their own, of which they may dispose freely within the framework of their powers, should be guaranteed to local administrations in national economic policy (Art. 9 of the European Charter of Local Self- Government). "Local own revenue sources are often utterly inadequate to finance the responsibilities assigned, while intergovernmental transfers are vulnerable to political manipulation, poorly designed allocation formulae and inappropriate conditions" (Devas \& Delay, 2006, p. 685). Decentralisation matters for strengthening local democracy because local administrations are inclined to produce solutions destined to generate capacity and financial resources. For this reason, Yilmaz and his colleagues (2010) argue that devolving a certain level of responsibility for expenditures to local government together with financial autonomy are a necessity.

In Turkey, the 2012 reforms increased the amount of intergovernmental transfers without giving local taxation powers to local administrations. The percentage of general tax revenues going to local governments was modified to increase the part of their total revenues stemming from transfers from the central state. The increase was most noteworthy for metropoli- 
$\tan$ municipalities, as more than $75 \%$ of their total revenues in 2015 came from such transfers (Y1lmaz \& Güner, 2017, p. 241). Yılmaz and Güner, who examined the results of recent modifications to the intergovernmental fiscal system, conclude that they did not reinforce the fiscal autonomy of local governments. "On the contrary, local governments are becoming heavily dependent on central government transfers. The decline in the share of own-source revenues weakens the downward accountability linkage towards citizens. The only positive aspect of these changes is that there is no conditionality imposed on transfer revenues - they are mainly unconditional for municipalities." (Yılmaz \& Güner, 2017, p. 247)

Yllmaz and Güner (2017, p. 248) also claim that in Turkey the (downward) accountability relationships between citizens and local governments are weak, given the limited ability of citizens to be involved in the local planning and budgeting processes. Significant obstacles impede access to information concerning municipal finances. "More importantly, there is a need for social scrutiny of local government budget and tracking of expenditure to ensure downward accountability of all local governments' financial operations" (Yılmaz \& Güner, 2017, p. 141). Upward accountability structures were introduced into the legal system, but it is difficult to claim that they were implemented effectively. In Turkey, the Court of Accounts is the main institution charged with financial regulation of public administration. But over the last decades, it has not filed any legal actions against AKP-controlled municipalities, even though it has identified and disclosed some irregular or illegal actions on their part. ${ }^{3}$ Indeed, strong accountability and transparency are not desirable for the central government as patronage and clientelistic relations at the local and metropolitan levels (as well as the central level) are particularly important for both national and local electioneering. The exchange of votes and in-kind or cash contributions for political patronage jeopardises downward accountability. As a consequence of the dependence of metropolitan municipalities on revenues transferred from the centre, as well as the decline of accountable, transparent institutions, local discretion and accountability have deteriorated (Yılmaz \& Güner, 2017, p. 247).

Indeed, patronage politics in municipalities are documented in several academic studies, including those of Aytaç (2014), who writes about the distribution of public goods and services in return for votes; Eligur, (2009), who studied the distribution of appliances, coal, and food baskets;

\footnotetext{
3 See https://www.sayistay.gov.tr/
} 
and Erder and İncioğlu (2008). Furthermore, Ağırel (2019) and Toker ${ }^{4}$ transcribed case files concerning corruption and scamming by AKP municipalities that were documented by the Court of Accounts ${ }^{5}$ but did not lead to any investigation because, as Çeviker-Gürakar and Bircan (2019) demonstrate, the AKP's political sustainability is assured by dependency networks. AKP municipalities established clientelistic networks that ensured the perseverance of the party by transferring colossal sums to politically connected private sector firms through outsourcing procurements. A substantial number of contracts was given to firms with close ties to the party or to those owned by municipal council members themselves. In that way, municipal procurements became the tools of favouritism and financing party politics. These municipalities also collaborated with Islamic charity organisations - ostensibly NGOs - that have close connections to AKP officials, including Erdoğan. By and large founded by AKP municipalities, these NGOs became the mediators in a politics of redistribution used to negotiate votes. Electoral losses in major cities in the most recent local elections damaged these dependency networks and thus the political stability of the AKP.

Especially after these electoral defeats, central state control over the finances of local administrations turned into an instrument of oppression used at the discretion of the ruling party. Indeed, the central state selectively opts not to hold municipalities that are under the control of the ruling party in check, which in turn threatens local democracy. Because of the poor management that accompanies patronage politics, the accumulated debt of these municipalities is growing exponentially. ${ }^{6}$ Istanbul, a city governed by the AKP or its founders since 1994, has a budget for 2019 of over 4 billion dollars. When transportation and water management agencies are included, the total budget exceeds 6 billion. According to the 2018 oversight report submitted to the parliament, the metropolitan municipality (including its 28 companies and partners) is 4 billion dollars in debt. Legitimate processes like financial audits are necessary and inevitable safeguards for local democracy, but the incontestably inefficient management over the last decades has never been scrutinised. Patronage politics has thus been one of the major impediments to the consolidation

${ }^{4}$ https://www.sozcu.com.tr/2019/yazarlar/cigdem-toker/ibbden-vakiflara-hizmet-raporu-3288303/

5 https://www.sayistay.gov.tr/

6 https:/www.al-monitor.com/pulse/originals/2019/04/turkey-istanbul-metropolitanmunicipality-goes-bankrupt.html 
of democracy in Turkey (Heper \& Keyman, 1998). The "AKP selectively enforced anti-corruption measures in a way that consolidates its power by changing existing intuitionalist structures. In this regard, anti-corruptionrelated institutional change in the public sector, to a great extent, accommodated corruption, instead of eliminating it" (Soyaltin, 2017, p. 452).

In an ironic twist, the incompetent management of municipalities was used as an argument to convince citizens to vote once again for the ruling party in the 2019 elections; AKP-governed municipalities, it was argued, could manage the predicament, but it would be a major impediment should the opposition take over. Underscoring the poor financial situation of municipalities (predominantly those that had for years been ruled by AKP-affiliated mayors), the president and chairman of the party, Erdoğan, stated in a televised interview on 27 March 2019, the eve of the local elections, that "municipalities that will not be in accord with the central administration will go bankrupt. They will not even be able to govern if they win." Similarly, given the AKP majorities in the local city councils of Istanbul and Ankara, the president called the new mayors-elect from the opposition "lame ducks."

Indeed, following its eventual defeat in the local elections, ${ }^{9}$ the central state created new tools to put financial pressure on metropolitan municipalities. A modification to the law on intergovernmental transfers that was adopted on 2 July 2019, reinforced the authority of the president over İlbank (previously Bank of Provinces), the institution that directs intergovernmental transfers to municipalities and SPAs apart from transfers that are directly channelled to metropolitan municipalities by the Ministry of Finance. Ilbank also provides financial support to local administrations with medium and long-term loans. Another modification to the same law adopted on 17 January 2019, handed the president control over the financial aides to be delegated to the municipalities by the Directorate of Strategy and Budget.

Ilbank thus has the power to withhold up to $40 \%$ of the transfer revenues of municipalities that are in arrears due to taxes, social security pay-

${ }^{7}$ https://tr.euronews.com/2019/04/03/herkesin-aklindaki-soru-istanbul-ve-ankara-erdogana-ragmen-yonetilebilir-mi-istanbul-ankar

${ }^{8}$ http://www.diken.com.tr/erdogan-ortada-topal-ordek-var-bu-secim-sembolik/

9 The AKP-led alliance lost the most important metropolitan municipalities; 11 of 30 cities passed into the hands of the opposition including the three largest ones. https:// www.ntv.com.tr/2019-yerel-secim/buyuksehirlerde-kazanan-partiler-31-mart-2019-yerel-secimleri,z-dL7nRrMkqMAolasrTw7Q 
ments, and other delinquent debts to public entities. These cuts were arbitrarily implemented especially for opposition municipalities run by the pro-Kurdish Halklarm Demokratik Partisi (HDP, or Peoples' Democratic Party). These deductions at the source, implemented without warning by the central state via İlbank, are a potential risk to the stability and predictability of the transfer system. The fact that these deductions were stopped for the four months before the 31 March 2019 local elections ${ }^{10}$ suggests the instrumentalisation of Illbank by the central state. Moreover, since the status of Ilbank was changed to a joint stock company in February 2011, the bank has ceased delivering comprehensive information about deductions at the source except for the total amount of transfers to SPAs and municipalities. Yslmaz and Güner (2017) state that the bank hides behind the banking law in rejecting requests for information (p. 245).

Another recent state intervention that put municipalities in a financially difficult position concerned the funding of subway construction realised by the central state on behalf of municipalities. On 30 April 2019, a presidential decree stipulated that a $5 \%$ cut would be taken from the municipalities' share of general tax revenues for this purpose. Previously, the cut was $5 \%$ of subway revenues. The newly-elected mayor of Ankara stated in his report on his first 100 days in office that this change meant the share paid by the municipality would be 20 times greater. ${ }^{11}$

The mayor of Istanbul has had to seek foreign loans for uncompleted infrastructure projects because Turkey's state lenders have refused financing for the municipality, and publicly owned banks have ceased extending even short-term credit to Istanbul and other municipalities controlled by the opposition. ${ }^{12}$ The government has even banned CHP-run metropolitan municipalities of Ankara, Istanbul and Izmir from collecting donations to help people in the fight against the COVID-19 pandemic, accusing them of acting without the permission from the state government. The bank accounts of the municipalities used for collecting donations have been blocked by the Ministry of the Interior. ${ }^{13}$

\footnotetext{
$10 \mathrm{https}: / / \mathrm{www} . c n n t u r k . c o m / e k o n o m i / b e l e d i y e-b o r c l a r i n a-4-a y-k e s i n t i-o l m a y a c a k$

11 https://www.birgun.net/haber-detay/mansur-yavasin-ilk-100-gunu-aciklandi-ankara-136-milyon-butce-fazlasi-verdi.html

12 https://www.al-monitor.com/pulse/originals/2019/11/istanbul-mayor-seeks-foreign-funding-infrastructure.html

13 https://www.eurasiareview.com/02042020-turkey-president-erdogan-accuses-municipalities-of-forming-parallel-state/
} 


\section{Control over the Decisions of Local Administrations and the Arbitrary Removal of Locally Elected Officials}

Intergovernmental relations have a substantial effect on the degree of control over local administrations' decisions. The autonomy of local administrations vis-ã-vis the central government is a delicate issue, so the relationship between a given local administration and the central state is crucial. The decisions of local authorities must be protected from arbitrary intervention by the central administration (Bland, 2011, p. 70). A good relationship guarantees the support of the centre, and this is the case when both local and central authorities belong to the same political party. On the other hand, municipalities controlled by opposition parties encounter many problems on the administrative and financial levels. Beltan (2018) argues that the central government, which was "heavily imbued by partisan politics and rivalry, blocked or obstructed opposition municipality projects in Izmir, ${ }^{14}$ a stronghold of the opposition (CHP) since the mid-1990s, and Diyarbakir; bastion of pro-Kurd parties. Although the center financed some large-scale transportation projects in İzmir, these were to show their capacity to transform the city into a competitive metropolis and to indicate their pledge for more in the case the governing party was to take over the metropolitan municipality." (Beltan, 2018, p. 145)

Opposition-affiliated municipalities also face numerous strategies designed to disgrace them, varying from auditing raids, heavily publicised corruption allegations targeting ranking municipal authorities including mayors, and condescending lectures by government officials. "İzmir's municipalities and the CHP leaders have claimed that the central government has been highly biased and inconsistent towards their municipalities and others across the country. They argued that the central government's dealings with İzmir's municipalities have been far from objective and fair, accusing the center of a campaign to defame their municipalities in order to win over the city in the future elections - national and local." (Beltan, 2018, pp. 147-148)

14 On 28 November 2018, the mayor of the city deplored the fact that the municipality had submitted a subway project for Buca to the Ministry of Development a year earlier but was still awaiting approval. https://www.izmir.bel.tr/tr/Haberler/izmire-su-yok/39202/156 
In Diyarbakır, both the lower and upper tiers of the metropolitan municipality are criticised by state officials regarding their performance in service delivery and their lack of competitiveness and efficiency in governing the metropolitan area. The municipalities, on the other hand, claim that municipal activities are deliberately blocked by the central state and its local agents (the governor and district governors) who "did not approve or put on hold many of their projects and cut their spending by obstructing the release of foreign funds for municipal projects" (Beltan, 2018, p. 196). Beltan further asserts that "the administrative tutelage had an added political bias - perception tutelage - in the region” (p. 239).

In Turkey, due to weakening institutions and excessive politicisation, the instruments for ensuring democratic governance themselves are frequently used as pretences for interference by the central state. This tendency towards strengthening the central state's control over local administrations accelerated during the state of emergency that was announced in the aftermath of the botched 2016 coup attempt and was sustained until 17 July 2018. A decree law issued by the government on 1 September 2016 was adopted by the parliament and became law on 10 November 2016. Amendments to the Law on Municipalities by Decree Law No. 674 (Art. 38 - 40) stipulated that appointed trustees would decide on replacement mayors, deputy mayors, and council members for those who were suspended, detained, or dismissed from public service in relation to the offense of aiding and abetting terrorism or terrorist organisations. Likewise, these amendments authorised state authorities to interfere in the local affairs of municipalities with respect to the fight against terrorism.

Thousands of elected mayors and councillors were dismissed in Kurdish provinces, and most were incarcerated indefinitely on the grounds that they were affiliated with the PKK and thus a threat to national security after the 2016 failed coup attempt. State officials, which is to say governors and district governors, were appointed to replace these dismissed mayors and councillors under the moniker "trustee" (kayym in Turkish), a novelty in Turkish public law. Eighty-one of the eighty-eight mayors dismissed by December 2016 were members of the pro-Kurdish Demokratik Bölgeler Partisi (DBP, or Democratic Regions Party) (Keles \& Ozgül, 2017, p. 310). The Diyarbakır municipality, considered the bastion of the Kurdish political movement, was the main target of such persecution (Kuyucu, 2018, pp. 1171-1172).

The Congress of Local and Regional Authorities of the Council of Europe states in Resolution No. 416, which was adopted on 29 March 2017, that 
Decree Law No. 674 is incompatible with the European Charter of Local Self-Government, that it could be used as a means to restrict local self-government, and that it contributed to a turn toward the "recentralisation" of Turkey in practice. The Council of Europe's Venice Commission further states that the provisions of the decree "allow interference by state authorities in the effective exercise of local self-government in certain municipalities in the context of the fight against terrorism." 15 The commission notes the congress' repeated calls for the abolition of administrative tutelage and for genuine decentralisation in Turkey. It calls on Turkish authorities to revoke the provisions introduced by the decree law. Keles and Ozgül (2017) further argue that the clauses added to the Law on Municipalities by the decree law, as well as the powers of appointment bestowed upon trustees are violations of the constitution (p. 306).

The local elections of 31 March 2019 constituted an important turning point for local politics in Turkey. The intervention of the central government in local politics acquired another dimension during which the president, once a politically neutral position, campaigned in favour of his party's candidates. However, the major opposition party, Cumburiyet Halk Partisi (CHP, or Republican People's Party) won in 11 of the 30 metropolitan municipalities including Istanbul, Ankara, Izmir, and Adana, while the HDP won in most of the eastern cities that had previously been placed under the administration of trustees. However, on 19 August 2019, less than five months after their election, the mayors of the HDP-ruled metropolitan municipalities of Diyarbakır, Van, and Mardin were dismissed on the grounds that they were under investigation for alleged misuse of public office and ongoing terror-related allegations. By 23 March 2020, the government had appointed trustees to 40 out of 65 municipalities won by the HDP since the March 2019 local elections. ${ }^{16}$ Replacements for these dismissed officials were appointed by the trustees, namely the governors of the respective cities. The practice of employing trustees has been predominantly reserved for Kurdish cities, whereas in western cities when a mayor is removed from duty due to an investigation, the municipal council elects a new mayor from within its ranks, as was the case for some AKP- and MHP-led municipalities in $2016 .{ }^{17}$ Indeed, the president

15 Venice Commission Opinion No. 888/2017

16 https://www.duvarenglish.com/politics/2020/03/23/turkey-detains-five-hdpmayors-as-crackdown-continues/

17 https://www.al-monitor.com/pulse/originals/2019/08/three-hdp-mayors-dismissedturkey-crackdown.html\#ixzz5xEbRcijF 
and chairman of the AKP, Erdoğan, declared before the 2019 local elections that trustees would be appointed immediately in Kurdish municipalities when there was a question of terror-related activity. ${ }^{18}$ However, in December 2019, the mayor of one of the district municipalities of İzmir metropolitan municipality elected from the main opposition party CHP, was dismissed from duty on 18 December 2019 over alleged links to the Gülen network. ${ }^{19}$

It is important to differentiate between the removal procedures for mayors and councillors affiliated with the governing party and those to which certain opposition-affiliated - which is to say, pro-Kurdish - mayors and councillors are subjected. Indeed, in September 2016 (foreshadowing the 2019 local elections), a number of sitting AKP mayors as well as provincial chairmen of the party were forced to resign at Erdoğan's behest under the pretext of remedying "fatigue" within the party. The mayors of Istanbul, Ankara, Bursa, and Balıkesir eventually announced their resignations over the course of 2017. According to the opposition, their removals were carried out in lieu of prosecuting them for alleged crimes, notably corruption. "Erdoğan (actually acknowledged) that some mayors from his party acted outside the law and he forced them to resign instead of handing them over to justice" (Hurtas, 2017). Indeed, no investigation has been opened into these mayors, and in these cities, metropolitan councils voted on a replacement mayor.

Turkey is in an ongoing process of democratic decline, and its political system is regressing into what some authors call "Erdoğanism" (Yilmaz \& Bashirov, 2018; Çağaptay \& Aktaş 2017), which combines elements of electoral authoritarianism, neopatrimonialism, populism, and Islamism. Frequent and fair elections with secret ballots that are conducted on the basis of direct, equal, universal suffrage are a minimum threshold for local democracy (Bland, p. 70; Council of Europe, 1985). Over the previous decade, scholars (Yilmaz \& Turner, 2019; Yilmaz \& Bashirov, 2018), political parties, and NGOs have expressed concern about the security and reliability of elections in Turkey. Several NGOs like Vote and Beyond $(\mathrm{O} y$ ve Otesi) were created to ensure transparency and observe ballot counts. Some 56 thousand volunteers successfully monitored Turkey's $7^{\text {th }}$ June and ensuing elections. Opposition parties along with non-governmental

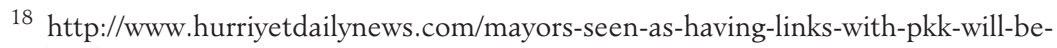
dismissed-erdogan-141479

19 https://www.duvarenglish.com/domestic/2020/02/11/govt-appointed-trustee-toclose-down-art-house-in-urla/ 
organisations and labour union confederations formed the Fair Election Platform before the 2018 presidential election. Concerns about election security and the impartiality of the Supreme Electoral Council have been substantiated, particularly during the 2019 local elections when the council resolved that mayors-elect who had previously been dismissed by a presidential decree in a crackdown following the 2016 failed coup attempt were not entitled to assume their offices even though the same council had approved their candidacy prior to the elections. ${ }^{20}$ The mandates in these contests were given to runner-up AKP candidates instead of rerunning the elections. Indeed, another debatable decision was the one to rerun the Istanbul election.

\section{Conclusion}

In Turkey, modifications to the system of local administration in the direction of recentralisation stem from the determination to strengthen the central state. There are two main pillars of territorial recentralisation: first, after the collapse of the so-called "peace process", the Kurdish question has been treated as an issue of security, order, and sovereignty. Embracing an extremely nationalist discourse, the state put the screws to HDP-ruled municipalities and disqualified mayors-elect in major Kurdish-populated cities. Although they have been covertly threatened with a similar measure, few trustees have been appointed to CHP municipalities. Second, "the provision of public welfare as 'charitable patronage', redistribution of public resources, and access to public jobs, health services and public housing" (Yilmaz \& Bashirov, 2018, p. 1819) constituted the major assets of dependency networks created between the AKP and its electors. Taking into account the crucial role played by municipalities in the constitution of these networks, control over municipalities became imperative for the central state. Because controlling them through the ballot box has turned out to be an arduous challenge, the prerogatives of municipalities have been progressively scaled back by the centre, and financial pressure has been put especially on those municipalities controlled by the opposition. The biased measures of the government particularly hit the municipalities led by the HDP and CHP, whereas it is questionable if municipalities led

20 https://www.turkishminute.com/2019/04/09/hdp-mayor-elect-not-given-mandatein-mardin-due-to-akp-objection/ 
by the ruling party do have much room to negotiate vis-ã-vis the central power anyway. Consequently, in Turkey, democratic practices at the level of local administration are in blatant regression.

Having lost one major mechanism for preserving a patronage politics that is nourished and maintained by local administrations to democratic alternation, the state may take further steps to reinforce its control and recentralisation. Indeed, a journalist close to the AKP has already mentioned Erdoğan's desire to eliminate the election of mayors in favour of a new system of centrally appointing them. ${ }^{21}$ Forced to cohabitate with opposition-affiliated local administrations, the central state may also attempt to limit the executive powers of mayors. Nevertheless, even in a marginalised local democracy, mayors still have some tools at their disposal and should put them into service to reinforce and expand democratic rights. The fact that municipal council meetings are now publicly broadcast and that investigations have been opened into the financial dealings realised during previous administrations already demonstrates that there are still opportunities to advance the local autonomy that is at risk.

\section{References}

Ağırel, M. (2019). Şaki [Robber]. Istanbul, Turkey: Inkilap.

Arıkboğa, E. (2013). Geçmişten geleceğe büyükşehir modeli [Metropolitan city model from past to future]. Yerel Politikalar, 3, 48-96.

Aytaç, S. E. (2014). Distributive politics in a multiparty system: The conditional cash transfer program in Turkey. Comparative Political Studies, 47(9), 12111237, https://doi.org/10.1177/0010414013495357

Bayraktar, U. (2018). Présidents avant-gardes: Les maires commes patrons des villes Turques [Avant-garde presidents: Mayors as patrons of Turkish cities]. Confluences Méditerranée, 4(107), 111-123, https://doi.org/10.3917/ come.107.0111

Beltan, S. B. (2018). Making and maintaining metropolises: Entrepreneurial municipalism in Turkey. (Doctoral thesis). Retrieved from https://tspace.library. utoronto.ca/bitstream/1807/89867/3/Beltan_Sude_201806_PhD_thesis.pdf.

Bland, G. (2011). Considering local democratic transition in Latin America. Journal of Politics in Latin America, 3(1), 65-98, https://doi. org/10.1177/1866802x1100300103

21 https://t24.com.tr/haber/erdogan-belediye-baskanlarinin-atamayla-goreve-gelmesi-daha-dogru-2019dan-sonra-gundeme-gelecek-dedi,486587 
Çeviker-Gürakar, E., \& Bircan, E. (2019). Redistributive politics, clientelism, and political patronage under the AKP. In L. R. de Elvira, CH Schwartz \& I Weipert-Fenner (Eds.), Clientelism and patronage in the Middle East and Nord Africa: Networks of dependency (pp. 71-97). New York, USA: Routledge, https://doi.org/10.4324/9781351169240-4

Cheema, S. G., \& Rondinelli, D. A. (2007). From government decentralization to decentralized governance. In S. G. Cheema \& D. A. Rondinelli (Eds.), Decentralizing governance: emerging concepts and practices, (pp.1-20). Washington, USA: The Brookings Institution, https://doi.org/10.1177/147309520 80070030504

Cohen, J. M., \& Peterson, S. B. (1999). Administrative decentralisation: Strategies for developing countries. West Hartford, USA: Kumarian Press.

Cole, A. (2012). The French State and its territorial challenges. Public Administration, 90(2), 335-350, https://doi.org/10.1111/j.1467-9299.2011.01955.x

Council of Europe (1985). European Charter of Local Self-Government [European Treaty]. Retrieved from https://rm.coe.int/168007a088

Dahl, R. A. (1971). Polyarchy: Participation and opposition. New Haven, USA: Yale University Press.

Devas, N., \& Delay, D. (2006). Local democracy and the challenges of decentralizing the state: An international perspective. Local Government Studies, 32(5), 677-695, https://doi.org/10.1080/03003930600896293

Diederichs, O., \& Luben, I. (1995). La Déconcentration [Deconcentration]. Paris, France: Presses Universitaires de France.

Eliçin, Y. (2014). Neoliberal transformation of the Turkish city through the Urban Transformation Act. Habitat International, 41, 150-155, https://doi. org/10.1016/j.habitatint.2013.07.006

Eliçin, Y. (2018) Metropolitan municipality reform: Rescaling of municipal service delivery in Turkey. In I. Koprić, H. Wollmann \& G. Marcou (Eds.), Evaluating reforms of local public and social services in Europe (pp. 291-308). London, UK: Palgrave Macmillan, https://doi.org/10.1007/978-3-319-61091-7_18

Eligur, B. (2009). Turkey's March 2009 local elections. Turkish Studies, 10(3), 469496.

Erder, S., \& İncioğlu, N. (2008). Türkiye'de Yerel Politikanın Yükselisi [Rise of local politics in Turkey]. Istanbul, Turkey: Bilgi Üniversitesi yayınları.

Falleti, T. G. (2005). A sequential theory of decentralization: Latin American cases in comparative perspective. American Political Science Review, 99(3), 327-346, https://doi.org/10.1017/s0003055405051695

Gözler, K. (2013). 6360 Sayili Kanun Hakkinda Elestiriler [Critics of the Law No. 6360]. Legal Hukuk Dergisi, 11(122), 37-82.

Heper, M., \& Keyman, E. F. (1998). Double-faced state: Political patronage and the consolidation of democracy. Middle Eastern Studies, 34(4), 259-277, https://doi.org/10.1080/00263209808701251 
Horga, I. (2017). De la décentralisation ã la recentralisation en Europe centrale et orientale, Le cas de la Roumanie [From decentralization to recentralization in Central and Eastern Europe, The case of Romania]. Pôle Sud, 46(1), 63-78, https://doi.org/10.3917/psud.046.0063

Hurtas, S. (2017). Erdogan's mayor purge leaves almost half of Turkey without elected officials, Al-Monitor. Retrieved from https://www.al-monitor.com/ pulse/originals/2017/11/turkey-local-administrations-in-turmoil.html

Keleş, R., \& Özgül, C. G. (2017). Belediye Organlarına "Kayyım” Atamaları Üzerine Bir Degerlendirme [An evaluation on the nominations of "trustees" to municipal organs]. Ankara Üniversitesi SBF Dergisi, 72(2), 299-313, https:// doi.org/10.1501/sbfder_0000002446

Kerléo, J. F. (2015) Concept de recentralisation et réformes territoriales en Europe et au-delã, [Concept of recentralization and territorial reforms in Europe and beyond]. Revue internationale de droit compare, 67(3), 795-821, https://doi. org/10.3406/ridc.2015.20543

Kuyucu, T. (2018). Politics of urban regeneration in Turkey: Possibilities and limits of municipal regeneration initiatives in a highly centralized country. Urban Geography, 39(8), 1152-1176, https://doi.org/10.1080/02723638.2018.1440 125

Lipset, S. M. (1995). The encyclopedia of democracy. Washington, USA: Congressional Quarterly Books.

Litvack, J., Ahmad, J., \& Bird, R. (1998). Retbinking decentralization in developing countries. Washington, USA: World Bank, https://doi.org/10.1596/0-82134350-5

Rondinelli, D. A. (1981). Government decentralization in comparative perspective: Theory and practice in developing countries. International Review of Administrative Sciences, 47(2), 133-145, https://doi.org/10.1177/002085238004700205

Röth, L., Kaiser, A., Varol, C., \& Sadioğlu, U. (2016). Centre-periphery conflict and ideological distance in Turkey. Swiss Political Science Review, 22(4), 585-607, https://doi.org/10.1111/spsr.12225

Santagati, M. E., Bonini Baraldi, S., \& Zan, L. (2020). Understanding decentralization: Deconcentration and devolution processes in the French and Italian cultural sectors. International Journal of Public Sector Management, 33(4), 435-460, https://doi.org/10.1108/ijpsm-02-2019-0050

Soyaltin, D. (2017). Public sector reforms to fight corruption in Turkey: A case of failed Europeanization? Turkish Studies, 18(3), https://doi.org/10.1080/146838 49.2017.1314185

Tansel, C. B. (2019). Reproducing authoritarian neoliberalism in Turkey: Urban governance and state restructuring in the shadow of executive centralization. Globalizations, 16(3), 320-335, https://doi.org/10.1080/14747731.2018.1502 494

Wollmann, H. (2007). Devolution of public tasks between (political) decentralisation and (administrative) deconcentration - in comparative (European) perspective. Social Science Japan, 37(September), 16-21. 
Yildizcan, C. (2018). Le pouvoir des élus vs le pouvoir des nommés, ou la recentralisation des pouvoirs locaux [The power of elected officials vs the power of the appointed, or the recentralisation of local authorities]. Confluences Méditerranée, 4(107), 137-149, https://doi.org/10.3917/come.107.0137

Yildizcan, C., \& Bayraktar, U. (2019). The empowerment of Turkish governors within hybrid settings of public administration. Mediterranean Politics, 24(3), 356-375, doi:10.1080/13629395.2017.1398889.

Yilmaz, I., \& Bashirov, G. (2018). The AKP after 15 years: Emergence of Erdoganism in Turkey. Third World Quarterly, 39(9), 1812-1830, https://doi.org/10 .1080/01436597.2018.1447371

Yilmaz, S., Beris, Y., \& Serrano-Berthet, R. (2010). Linking local government discretion and accountability in decentralization. Development Policy Review, 28(3), 259-293, https://doi.org/10.1111/j.1467-7679.2010.00484.x

Y1lmaz, S., \& Güner, A. (2017). Impact of recent changes on local government discretion and accountability in Turkey. Marmara Journal of Economics, 1(2), 229-250, https://doi.org/10.24954/mjecon.2017.12

Yllmaz, Z., \& Turner, B. S. (2019). Turkey's deepening authoritarianism and the fall of electoral democracy. British Journal of Middle Eastern Studies, 46(5), 691-698, https://doi.org/10.1080/13530194.2019.1642662 


\section{THE UNBEARABLE FAILURE OF DECENTRALISATION IN TURKEY}

\section{Summary}

Due to the country's then drive towards European Union membership, a comprehensive administrative reform agenda had emerged in Turkey during early 2000s. But a brusque reversal of decentralisation reforms followed the 2010 constitutional referendum. The democratic reform agenda adopted in the 2000s has been overturned to lead to an increasingly authoritarian and centralised power. This recentralisation movement had a direct impact on local governance, triggering a decline of local autonomy accompanied by the dismissal of elected mayors and city council members in some Kurdish-populated cities. The fast decay of democratic accountability was accompanied by clientelism and corruption. Indeed, modifications to the system of local administration in the direction of recentralisation stem from the determination to strengthen the central state. Embracing an extremely nationalist discourse, on the one hand, the state put the screws to HDP-ruled municipalities and disqualified mayors-elect in major Kurdish-populated cities. On the other hand, the provision of public welfare as 'charitable patronage', redistribution of public resources, and access to public jobs, health services and public housing constituted the major assets of dependency networks created between the AKP and its electors. Taking into account the crucial role played by municipalities in the constitution of these networks, control over municipalities became imperative for the central state. Nevertheless, even in a marginalised local democracy, mayors still have some tools at their disposal and should put them into service to reinforce and expand democratic rights.

Keywords: decentralisation, local autonomy, recentralisation, local reform, local democracy 


\section{NEPODNOŠLJIVI NEUSPJEH DECENTRALIZACIJE U TURSKOJ}

\section{Sažetak}

Zbog težnji prema članstvu u Europskoj uniji u Turskoj je početkom 2000-ih počela sveobubvatna upravna reforma. Medutim, nakon ustavnoga referenduma 2000. uslijedio je oštar preokret u pogledu decentralizacijskih reformi. Program demokratskib reformi usvojen 2000-ib ukinut je te se krenulo u smjeru sve autoritarnije $i$ centraliziranije vlasti. Taj pokret ponovne centralizacije izravno je utjecao na lokalno upravljanje, dovevši do smanjenja lokalne autonomije te razrješenja izabranih gradonačelnika i članova gradskib vijeća u nekim gradovima s kurdskim stanovništvom. Brzo slabljenje demokratske odgovornosti bilo je popraćeno klijentelizmom i korupcijom. Promjene sustava lokalne samouprave u smjeru ponovne centralizacije proizlaze iz odlučnosti da se ojača središnja država. Usvajajući krajnje nacionalistički diskurs, država je, s jedne strane, vršila pritisak na općine kojima upravlja HDP (politička stranka Halklarm Demokratik Partisi) $i$ diskvalificirala izabrane gradonačelnike u najvecim gradovima s kurdskim stanovništvom. S druge strane, pružanjem socijalne skrbi kao milosrdne zaštite, preraspodjelom javnih sredstava i pristupom poslovima u javnom sektoru, zdravstvenim uslugama $i$ socijalnom stanovanju AKP-a (politička stranka Adalet ve Kalkınma Partisi) stvarala je mrežu ovisnosti svojib birača. Imajući u vidu ključnu ulogu koju su općine igrale u pružanju tib usluga, kontrola nad općinama postala je imperativ. Unatoč tomu, čak i u marginaliziranoj lokalnoj demokraciji, gradonačelnici još uvijek imaju na raspolaganju neka sredstva koja trebaju iskoristiti kako bi ojačali i proširili demokratska prava.

Ključne riječi: decentralizacija, lokalna autonomija, recentralizacija, reforma lokalne samouprave, lokalna demokracija 